Al-Bidayah : jurnal pendidikan dasar Islam

Volume 12, Number 2, December 2020

ISSN: 2549-3388 (online)

Available online at https://jurnal.albidayah.id

Submitted: October 10, 2020, Accepted: December 29, 2020

\title{
INTERNALIZATION OF HUMANISTIC VALUES FOR EARLY AGES CHILDREN IN FACING PANDEMIC COVID-19
}

\author{
Asfiati Asfiati ${ }^{1}$, Sutrisno Sutrisno ${ }^{2}$, Nur Imam Mahdi ${ }^{3}$, Muhammad Aswin ${ }^{4}$ \\ IAIN Padangsidimpuan, Indonesia ${ }^{1,3}$, UIN Sunan Kalijaga Yogyakarta, Indonesia ${ }^{2}$, \\ UIN Sumatera Utara Medan, Indonesia ${ }^{4}$ \\ E-mail: asfiati@iain-padangsidimpuan.ac.id ${ }^{1}$,trisno_63@yahoo.com² ${ }^{2}$ \\ imam@iain-padangsidimpuan.ac.id ${ }^{3}$, muhammadaswin@uinsu.ac.id ${ }^{4}$
}

DOI: $10.14421 /$ al-bidayah.v12i2.578

\begin{abstract}
This research discusses the internalization of human values in children facing the COVID-19 pandemic in Padangsidimpuan. It was found that there were actions that were inappropriate for mothers, teachers and the community. Mothers understand the COVID-19 pandemic from a negative point of view. Mother forbids the children to see each other. The teacher advised the children not to leave the house. People advise children not to play outside of parental guidance. These are all inappropriate actions in understanding social distancing and staying at home as one of the government's appeals. However, it can follow play, study, and gather protocols. Therefore, it is necessary to conduct research on how the actions of mothers, teachers and society in children face the COVID-19 pandemic? How to internalize human values against the COVID-19 pandemic in Padangsidempuan City? The results of the study found that mothers, teachers, and the community provided a more appropriate understanding of children and instilled the importance of being grateful to Allah SWT, feeling empathy for children whose parents were indicated to have COVID-19 and internalizing egalitarian, humanitarian attitudes, namely respect, care. , share, strengthen hearts, and put forward identity so that life becomes useful.
\end{abstract}

Keywords: humanistic values; early ages children; pandemic COVID-19

\section{INTRODUCTION}

COVID-19 is a world problem. Problems that affect every activity. Problems that start from the ongoing pandemic coronavirus 2019. COVID-19 impact for the world of education, psychology, comfort, security, and economic circulation. Based on this condition, the World Health Organization states that the COVID-19 problem is an emerging public health problem of international concern. CoV-2). The outbreak was identified in Wuhan, China, in December 2019. ${ }^{1}$ The term covid pandemic 19 corresponds to the ongoing coronavirus in December 2019 in China and is a global problem.

1 WHO, "Novel Coronavirus-China". WHO. Retrieved 9 April 2020," World Health Organization, 2020, https://www.who.int/indonesia/news/novel-coronavirus. 
The World Health Organization declared "the outbreak of a Public Health Emergency of International Concern on January 30, and a pandemic on March 11". ${ }^{2}$ Indonesia also experienced a covid pandemic 19. The government issued a state of disaster emergency from February 29, 2020, to May 29, 2020. ${ }^{3}$

Pandemics have caused severe global socio-economic disruption. Delays or cancellations of sporting, educational, religious, political, artistic, and cultural events experienced by each country. According to UNICEF monitoring, 186 the country currently implements national closure and eight implements local closure, affecting around 98.5 percent of the world's student population. ${ }^{4}$ Schools, universities, and colleges have been closed both nationally and locally in 197 countries.

As a result of the COVID-19 problems, the community is confused and panicked. Where is the cause of the coronavirus's emergence so suddenly, and its handling is not yet specifically available? Kumar even revealed the difficulty of handling COVID-19 as follows, "There is no unique vaccine for this yet. Only supportive therapy is the treatment strategy followed by health professionals. Some research studies claimed that ribavirin and interferon-alpha had been offered". 5 With this condition, people are nervous, the world of panic, and children become part of the panic and awkwardness to face the covid pandemic 2019.

The research has encouraged each individual to protect themselves and all walks of life. A part of information makes a child's mind uneasy, like a statement stating the coronavirus can infect everyone. Mitra and Mitra declare,

"It has been demonstrated that the novel coronavirus can taint individuals everything being equal, at the Sametime, similarly as with every single viral disease, there are individuals with greater dangers of bullying. Kids, seniors, people with an undermined safe framework, and individuals with wellbeing

2 WHO, "Statement on the Second Meeting of the International Health Regulations (2005) Emergency Committee Regarding the Outbreak of Novel Coronavirus (2019-NCoV) 30 January 2020 Statement Geneva, Switzerland," World Health Organization, 2020, https://www.who.int/newsroom/detail/30-01-2020-statement-on-the-second-meeting-of-the-international-health-regulations-(2005)emergency-committee-regarding-the-outbreak-of-novel-coronavirus-(2019-ncov).

${ }^{3}$ Dana Riksa Buana, “Analisis Perilaku Masyarakat Indonesia Dalam Menghadapi Pandemi Virus Corona (Covid-19) Dan Kiat Menjaga Kesejahteraan Jiwa," SALAM: Jurnal Sosial Dan Budaya Syar-I 7 , no. 3 (2020): h. 218., https://doi.org/10.15408/sjsbs.v7i3.15082.

4 UNICEF, "Dampak Pandemic Corona Virus 2019-2020 Bagi Pendidikan," Cambridge International Examinations, 2020 , ttps://translate.google.com/translate?u=https://en.wikipedia.org/wiki/Impact_of_the_2019\%25E2\%2580 \%259320_coronavirus_pandemic_on_education\&hl=id\&sl=en\&tl=id\&client=srp.

5 Dharmendra Kumar, "Corona Virus: A Review of COVID-19," Eurasian Journal of Medicine and Oncology, 2020, https://doi.org/10.14744/ejmo.2020.51418. 
conditions, for to secure ourselves and the individuals around us, we have to take the correct preventive measures and be aware of our environment. Starting A few models are Salmonella and E.coli". 6

In the situation of young children who are in the process of growth and development, they need accompanied and guided in dealing with a crisis. Such is the case with the outbreak of the COVID-19 problem in Padangsidimpuan. Padangsidimpuan, is a small city, must improve itself in the face of COVID-19. Padangsidimpuan, whose population consists of the family community. The family is undoubtedly alert and concerned about the world's state, the covid pandemic situation 19. In this case, the family, and other core familie, must be wise and pay attention and provide information and new things for early childhood, with updates, precise and clear. Early childhood is the category of the child age range from newborns up to 8 year. Gustina stated, "Based on pedagogical aspects, an early age is a foundation or initial foundation for further growth and development." 7

Even if there is an error in providing information, the family must be responsive and continue to follow and convey the correct information. Even the people of Padangsidimpuan city sometimes do not understand what to do in following the information of COVID-19 pandemic due to welfare and survival issues. ${ }^{8}$ The protocols of health seems like they may be met, with the condition that they may not touch each other, need to be informed to the child. Social distancing as a movement to break the spread of the coronavirus chain can be applied. Important children are given an understanding of keeping a distance of 1 to 2 meters.

Parenting strategy for children with humanist values seems to be important to deal with the COVID-19 pandemic. Humanist values that reflect themselves and behavior require consideration from subjective to objective nature. Humanist values prioritize the human spirit by considering the feelings, desires, hopes, and aspirations to understand each human being's behavior. ${ }^{9}$ Humanist values create an atmosphere of

${ }^{6}$ Saurabh Mitra and Jayati Chatterjee Mitra, “A Focus on Corona Virus (Covid-19)," International Journal of Research in Pharmaceutical Sciences 11, no. SPL1 (2020): 23-30, https://doi.org/10.26452/ijrps.v11ispl1.2009.

${ }^{7}$ Fatma Gustina, “Perkembangan Kognitif Anak Usia 4-5 Tahun Di TK Islam,” Jurnal Pendidikan $\begin{array}{lllll}\text { Anak Awlady } & 6, & \text { no. } & 1 & \text { (2020), }\end{array}$ https://www.syekhnurjati.ac.id/jurnal/index.php/awlady/article/view/5592/2913.

${ }^{8}$ Observation, "The State of Padangsidimpuan city in the atmosphere of the Covid-19 pandemic" (Padangsidimpuan City, 2020)).

${ }_{9}^{9}$ Asfiati, "Internalisasi Pendekatan Humanis Dalam Kurikulum Tersembunyi," Darul Ilmi 07, no. 01 (2019): 45-59, http://jurnal.iain-padangsidimpuan.ac.id/index.php/DI/article/view/1804/1563. 
wholeness. But the phenomenon in Padangsidimpuan city society makes the COVID-19 pandemics an atmosphere of horror, understanding, and fear. Early childhood feels psychological pressure and anxiety in learning, playing, behaving, and behaving. The mother, as a parent who is close to the child, is sometimes wrong in positioning herself to convey the atmosphere of the pandemic COVID-19. The mother conveys covid pandemic 19 information incompletely and is not from an accurate source. ${ }^{10}$ It's the same with the teacher at the time before the pandemic COVID-19 had not spread to the area, especially the city of Padangsidimpuan, the teachers did not convey important information to their students at all. ${ }^{11}$ The mistakes of mothers, parents and teachers in addressing the pandemic COVID-19 problem surely the people of Padangsidimpuan City did the same thing. Mother, parents, teachers are part of the Padangsidimpuan city community.

The field's phenomenon was also seen that the people of Padangsidimpuan city were so unwilling to know about the pandemic COVID-19. Information, The community continued to carry out their activities as usual. The district did not heed the protocol that the Padangsidimpuan city government appealed. Social distancing is ignored. Associations are still visible in hawker food centers, cafes. Padangsidimpuan city community still holds weddings, family gatherings. Tourist attractions are still full of young children, such as water parks in South Sidimpuan and Batunadua. ${ }^{12}$ If observed, this phenomenon is the fault of mothers, parents, and teachers who ignore government appeals. In this case, addressing the world of pandemic COVID-19 early childhood needs to be guarded, guided, and conveyed COVID-19 pandemic information.

Based on the conditions in Padangsidimpuan Town people where mothers, parents, teachers, and community members are significant to explore the internalization of human values for young children in facing the COVID-19 pandemic. Where mothers, parents, teachers, and the community should understand the COVID-19 pandemic from the positive side. While in the field, mothers forbid children from seeing each other.

\footnotetext{
${ }^{10}$ Observation, "The State of Padangsidimpuan city in the atmosphere of the Covid-19 pandemic" (Padangsidimpuan City, 2020).

${ }^{11}$ Observation, "The State of Padangsidimpuan city in the atmosphere of the Covid-19 pandemic" (Padangsidimpuan City, 2020).

12 Observation, "Condition of Padangsidimpuan City community in 6 City Subdistricts, In North Padangsidimpuan District, South Padangsidimpuan, Southeast Padangsidimpuan, Padangsidimpuan Batunadua, Padangsidimpuan Hutaimbaru, Padangsidimpuan Angkola" (Padangsidimpuan, 2020).
} 
Teachers' appeals to stay at home should convey the techniques for doing activities outside the home following government recommendations where the teacher suggests children wear masks. Children keep a distance of 1 meter. Children always wash their hands with pour water. Children wash hands with sanitizer after handling an object. Likewise, the community should suggest that children not play outside without parental guidance.

\section{Humanist Values}

Values produce something worthwhile. Humanist values impact coordinated attitudes, actions, and behavior. Humanist values provide freedom. Paulo Freire's perfective is popular oppositional to the dominant perspective use in educational reform the modern character societies humanism for social justice. ${ }^{13}$ This idea strengthened the fundamental humanitarian principles that gave rise to a sense of social justice and nonviolence. ${ }^{14}$

Humanist values reflect self-confidence and the ability to develop selfpotential. ${ }^{15}$ Internalization of humanist values gives rise to love each other and find meaning in one's existence. "Physical growth does not provide behavioral development. Change or development is only caused by the learning process, such as changing habits or habits, various abilities in terms of knowledge, attitudes, and skills. ${ }^{16}$

In the view of humanism, humans hold control of life and behavior. Every human being has the full right to develop his attitude and personality. The humanist religious view is through exemplary, heart approach, family approach by providing comfort, building a positive mindset, making habituation about praiseworthy behavior such as honesty, giving meaning to life and most importantly affirming aqidah. ${ }^{17}$

\footnotetext{
${ }^{13}$ Georgios Crollios, Paulo Preire and The Curriculum (New York: Roudledge, 2016), https://books.google.co.id/books?id=SRbvCgAAQBAJ\&pg=PT176\&dq=Paulo+Freire, $+2002:+195 \&$ hl=i d\&sa=X\&ved=0ahUKEwijr6XH_p3pAhWLaCsKHcl_CMwQ6wEILTAA\#v=onepage\&q=Paulo Freire\%2C 2002\%3A 195\&f=false.

${ }^{14}$ Abdul Azis, "Pendidikan Islam Humanis Dan Inklusif," Al-MUNZIR 9, no. 1 (March 24, 2020): 1-12, https://doi.org/10.31332/am.v9i1.773. 2016).

${ }^{15}$ Asfiati, Pendekatan Humanis Dalam Pengembangan Kurikulum (Bandung: Perdana Publishing,

${ }^{16}$ Budi Agus Sumantri, "Teori Belajar Humanistik Dan Implikasinya Terhadap Pembelajaran Pendidikan Agama Islam," Foundatia Jurnal Pendidikan Dasar 3, no. 2 (2019): 1-18, https://doi.org/https://doi.org/10.36088/fondatia.v3i2.216.

17 Puspo Nugroho, "Internalisasi Nilai-Nilai Karakter Dan Kepribadian Mahasiswa Pendidikan Agama Islam Melalui Pendekatan Humanis-Religius," Edukasia : Jurnal Penelitian Pendidikan Islam 12, no. 2 (2017): 355, https://doi.org/10.21043/edukasia.v12i2.2491.
} 
These expressions are part of internalizing the humanist values for early childhood through a humane approach with a sense of gratitude to the Divine (the value of humanism gratitude). ${ }^{18}$ The human approach is carried out in a dialogical, reflective, and expressive manner. ${ }^{19}$ Humanist values are internalized logically Divine Values are manifested in the form of relentlessness to the creator. Khuznudzhon to Khalik can calm the mind, especially the minds of young children. Khuznudzhon is a form of responsibility towards oneself implicitly and to the Lord explicitly. ${ }^{20}$

Humanist values move individuals into enthusiasm. Abdullah said, "Humanism, as one of the fields of philosophy studies, presents fervency for better human lives." ${ }^{21}$ Early childhood needs to be given reinforcement and information from some humanism literacy $^{22}$ so that they can display the best human figure who is always able to provide benefits for others.

\section{Early Childhood}

Age has a different range. Different age ranges have different characteristics. Early childhood in terms of age is in the field of 0-8 years. Based on the "National Children who are part of other humans. Association for the Education of Young Children (NAEYC) is an association of child educators based in America. Early childhood's age range is divided into 0-3 years, 3-5 years, and 6-8 years. "Early childhood is a unique individual who has a pattern of growth and physical development, cognitive, socio-emotional, creativity, language and communication that are specific to the stage being passed by the child. " 23

\footnotetext{
${ }^{18}$ Edy Junaedi Sastradiharja, Farizal Ms, and Al Firdaus, "Kecerdasan Interpersonal Humanistik Dalam Perspektif Al-Qur'an,” Andragogi: Jurnal Pendidikan Islam dan Manajemen Pendidikan Islam 2, no. 1 (March 25, 2020): 1-17, https://doi.org/10.36671/andragogi.v2i1.80.

${ }^{19}$ Khairul Nizam bin Zainal Badri and Hari Khrisnan Andi, "Kepentingan Pendidikan Humanistik Dalam Pengembangan Psikologi," Dinamika Jurnal Ilmiah Pendidikan Dasar 12, no. 1 (April 5, 2020): 33-43, https://doi.org/10.30595/dinamika.v12i1.5902.

${ }^{20}$ Bayu Fermadi, "Humanisme Sebagai Dasar Pembentukan Etika Religius; Dalam Perspektif Ibnu Athā'Illah Al-Sakandarī,” Jurnal Islam Nusantara $2, \quad$ no. $1 \quad$ (2018): 72, https://doi.org/10.33852/jurnalin.v2i1.71.

${ }^{21}$ Muhammad Luthfi Abdullah, "Religious Cultural-Based Educational Model Through Mentoring to Form Islamic Humanistic Values," Istawa: Jurnal Pendidikan Islam (IJPI) 5, no. 1 (2020): 1-18, https://doi.org/10.24269/ijpi.v5i1.2234.

${ }^{22}$ Hamidullah Ibda, "Contextualization of Religious Humanism Perspective of Mohammed Arkoun," At-Tajdidi-Jurnal Ilmu Tarbiyah $9, \quad$ no. 1 (2020): 17-48, http://ejournal.stitmuhpacitan.ac.id/index.php/tajdid/article/view/159/78.

${ }^{23}$ Sigit Purnama and Laily Hidayati, "Pengasuhan Anak Usia Dini Dalam Hikayat Indraputra," Jurnal Obsesi: Jurnal Pendidikan Anak Usia Dini 4, no. 2 (2020): 520-42, https://doi.org/10.31004/obsesi.v4i2.391.
} 
Early childhood is a group of people who are in the process of growth and development. ${ }^{24}$ Early childhood, according to their growth, can be guided and fostered. Attention and affection affect the child's self-regulation, which will be seen in the child's behavior. ${ }^{25}$ The story of physical and spiritual activities that are following growth and development can be capital to prepare children to enter the world of education. ${ }^{26}$

Many children go through essential and unique difficulties (a highly eventful and memorable period of life). ${ }^{27}$ Social development, psychological development, feelings, emotions, anxiety, neuroticism, and morals. ${ }^{28}$ To facilitate the child's growth and development. As expected, Law Number 20 of 2003 concerning the National Education System Article 1 number 14 states, "Early Childhood Education (PAUD) is a coaching effort aimed at children from birth until the age of six carried out through the provision of educational stimuli to assist in physical and spiritual growth and development so that children have the readiness to enter further education." 29

The condition of early childhood must be considered thoroughly in life and life. ${ }^{30}$ Early childhood is not anxious, not timid. Early childhood development takes place on an ongoing basis. ${ }^{31}$ Continuity, in the example, togetherness, morals,

${ }^{24}$ Ihsan Maulana and Nurhamidah Nasution, "Pengenalan Konsep Perkalian Menggunakan Media Rak Telur Rainbow Pada Anak Usia Dini Abstrak," Jurnal Obsesi : Jurnal Pendidikan Anak Usia Dini 4, no. 2 (2020): 512-19, https://doi.org/10.31004/obsesi.v4i2.370.

${ }^{25}$ Lidia Anjelina et al., "Pengaruh Keterlibatan Orangtua Dan Regulasi Diri Terhadap Perilaku Bullying Anak Usia Dini," Jurnal Obsesi : Jurnal Pendidikan Anak Usia Dini 4, no. 1 (2020): 715-32, https://doi.org/10.31004/obsesi.v4i2.438.

${ }^{26}$ Nurheliza Yunika and Ria Novianti, "Hubungan Konsep Diri Dengan Perilaku Moral Anak Usia Dini," Aulad: Journal on Early Childhood 2, no. 3 (2019): 73-80, https://doi.org/10.31004/aulad.v2i3.36.

27 Eti Nurhayati, "Memahami Tumbuh Kembang Anak Usia Dini:Perspektif Psikologi Perkembangan," Awlady: Jurnal Pendidikan Anak, 1, no. 2 (2015): 1-14.

${ }^{28}$ Setiani Widiyati, Anita Chandra, and Purwadi Purwadi, "Analisis Kecemasan Anak Tk Di Awal Masuk Sekolah Dalam Interaksi Didalam Kelas Di Kecamatan Pedurungan Kota Semarang," Yaa Bunayya: Jurnal Pendidikan Anak Usia Dini 3, no. 2 (December 27, 2019): 91-96, https://doi.org/10.24853/yby.3.2.91-96.

29 President of the Republic of Indonesia, Law of the Republic of Indonesia Number 20 of 2003 concerning the National Education System, The Ministry of State Secretariat of the Republic of Indonesia, vol. $19 \quad$ (Jakarta, 2003), https://kelembagaan.ristekdikti.go.id/wpcontent/uploads/2016/08/UU_no_20_th_2003.pdf.

${ }^{30}$ Ery Khaeriyah, "Membangun Kesadaran Moral Melalui Pendidikan Anak Usia Dini," Jurnal Pendidikan Anak Awlady 1, no. 2 (2015): 1-14.

31 Tamsik Udin, "Mengenali Anak Usia Dini Melalui Pertumbuhan Perkembangan Dan Karakteristiknya," AWLADY: Jurnal Pendidikan Anak 1, no. 2 (August 31, 2015), https://doi.org/10.24235/awlady.v1i2.744. 
democratic attitude, open and honest attitude. ${ }^{32}$. Thus the appreciation of early childhood from all walks of life emerged by itself.

\section{COVID-19 Pandemic}

COVID-19 pandemic raises many facts for various countries in the world. All of these facts affect the process of psychological growth and development of children. Mother as a parent and transmitter educator experiences some worries in providing calmness and affection to children in the face of a co-pandemic 19. On December 31, 2019, Chinese health authorities reported an outbreak of typical pneumonia in Wuhan. On January 7 COVID-19 is one of several zoonotic coronaviruses known to affect humans. ${ }^{33}$

Madjid et.al. said, "The first human $\mathrm{CoV}(\mathrm{HCoV})$ was identified in the mid1960s in human embryonic tracheal organ cultures, and until 2003".34 Extreme awareness, vigilance, and supervision are also needed to prevent this life-threatening viral disease. Al-Hazmi stated,"Even though there is improvement in our knowledge about Corona-virus, together with the absolute origin, possible ways of transmission and exact treatment. More efforts are still needed to accelerate the improvement of effective therapy and vaccination." 35

There are many ways to minimize the panic of the COVID-19 pandemic. Educational aspects can be done by learning virtually. These steps are used together with individual protective measures against COVID-19. WHO has stated,

"WHO recommended social and physical distancing measures to slow the spread of the disease by stopping the chain of transmission of COVID-19 and preventing the emergence of new ones. These measures secure physical distance between people and reduce contact with contaminated surfaces while encouraging and maintaining virtual social relationships within families and communities." 36

32 Ahmad Yani, Ery Khaeriyah, and Maulidya Ulfah, "Implementasi Islamic Parenting Dalam Membentuk Karakter Anak Usia Dini Di RA At-Taqwa Kota Cirebon," Jurnal Pendidikan Anak Awlady 3, no. 1 (2017): h.153-174, www.syekhnurjati.ac.id/jurnal/index.php/awlady.

33 Matthias Beck and Damian Tobin, "The 2019/2020 Novel Corona Virus Outbreak: An International Health Management Perspective," The Open Public Health Journal 13, no. 1 (2020): 52-54, https://doi.org/10.2174/1874944502013010052.

${ }^{34}$ Mohammad Madjid et al., "Potential Effects of Coronaviruses on the Cardiovascular System: A Review," JAMA Cardiology, 2020, https://doi.org/10.1001/jamacardio.2020.1286.

35 Ali Al-Hazmi, "Challenges Presented by MERS Corona Virus, and SARS Corona Virus to Global Health," Saudi Journal of Biological Sciences, 2016, https://doi.org/10.1016/j.sjbs.2016.02.019.

36 WHO, “\#Covid19 Coronavirus Disease 2019: Situational Report 72," DroneEmprit 2019, no. April (2020): 1-19, https://pers.droneemprit.id/covid19/. 
Mehta e.al also stated, "We recommend identification and treatment of hyper inflammation using existing, approved therapies with proven safety profiles to address the." ${ }^{37}$ In this case, the recommendations from various parties to identify and carry out good treatment using therapy are safe steps where COVID-19 is a virus of new infections. "The basic reproduction number is a central concept in infectious disease epidemiology, indicating the risk of an infectious agent concerning epidemic spread," 38 and so that the coronavirus did not carriers could transmit.

School closure, inadequate resources for medical response must be considered. These effects can be translated into a series of emotional reactions (distress or psychiatric conditions), unhealthy behavior, and non-compliance with public health directives. The study found that psychological conditions are disasters in mental health where emotional distress results from findings found in populations affected by the COVID-19 pandemic.

"Public health emergencies may affect the health, safety, and wellbeing of both individuals. These effects may translate into a range of emotional reactions (such as distress or psychiatric conditions), unhealthy behaviors. Extensive research in disaster mental health has established that emotional distress is ubiquitous in affected populations - a finding certain to be echoed in populations affected by the COVID-19 pandemic". ${ }^{39}$

\section{RESEARCH METHODS}

The approach to this research is qualitative, with phenomenology conducting a critical analysis of social phenomena, describing them in the written or spoken words of the people and the observed behavior. ${ }^{40}$ Researchers use these approaches for the results of the research can be objective and scientific. The researcher acts as a binding instrument and delays (aphoce) existing or assumptions. The researcher tries to establish communication with informants more closely, intimate, and empathize, to gain a deeper understanding of the situation, so that the data obtained becomes more expansive, more

\footnotetext{
${ }^{37}$ Puja Mehta et al., "COVID-19: Consider Cytokine Storm Syndromes and Immunosuppression," The Lancet 395, no. 10229 (2020): 1033-34, https://doi.org/10.1016/S0140-6736(20)30628-0.

38 Ying Liu et al., "The Reproductive Number of COVID-19 Is Higher Compared to SARS Coronavirus," Journal of Travel Medicine 27, no. 2 (2020): 1-4, https://doi.org/10.1093/jtm/taaa021.

39 Betty Pfefferbaum and Carol S. North, "Mental Health and the Covid-19 Pandemic," New England Journal of Medicine, 2020, https://doi.org/10.1056/nejmp2008017.

${ }^{40}$ Marjorie DeVault, Steven J. Taylor,,Robert Bogdan, Introduction to Qualitative Research Methods: A Guidebook and Resource, 4th ed. (Canada: Jhon Wiley \& Sons Incs Hoboken, 2016), https://books.google.co.id/books?id=jauBCgAAQBAJ\&printsec=frontcover\&dq=inauthor:\%22Marjorie+ DeVault\%22\&hl=id\&sa=X\&ved=0ahUKEwirj5bkpvpAhUL4XMBHf3CDCUQ6AEIKDAA\#v=onepage \&q\&f=false.
} 
accurate. Still, the informant's distance is always maintained so that researcher is more able to get objective and accurate data.

This research which is located in the Town of Padangsidimpuan, is based on the consideration that Padangsidimpuan is one of the Towns Province of North Sumatera that concerns children's education and psychology. ${ }^{41}$ Padangsidimpuan Town also has schools early childhood education units spread in 6 sub-districts of Padangsidimpuan Town, they are: North Padangsidimpuan, South Padangsidimpuan, Southeast Padangsidimpuan, Batunadua Padangsidimpuan, Padangsidimpuan Hutaimbaru, and Padangsidimpuan Angkola. ${ }^{42}$

The research respondents are mothers who have early childhood aged 0-8 years as many as 60 respondents spread in 6 districts in Padangsidimpuan. The other respondents are children aged 0-8 years who stay at home. Learn at home, play at home, worship at home, socialize with family at home.

The research procedure is carried out with the following phases. The first phase is conducting preliminary studies in 6 (six) districts in Padangsidimpuan Town using a questionnaire instrument. The results are analyzed to determine the focus of the research. The second phase, data collection by techniques: (1) participant observation, the researcher observes firsthand ${ }^{43}$ mothers in conveying information about pandemic covid to early childhood at home; (2) in-depth interviews with informants, starting with informants who are considered to be most concerned with the pandemic COVID-19, namely 8-year-old children accompanied by mothers who indicate who the next informant will be interviewed in-depth, and so on until the data obtained is saturated, meaning that information does not appear new, so information is obtained for research purposes. ${ }^{44}$ Data validity is achieved by triangulation of sources of triangulation of data collection techniques. The third phase, data analysis after completion in the field,

${ }^{41}$ Mrs. A, "Interview with Raudhatul Athfal teacher" (Padangsidimpuan Tenggara, 2020).

${ }^{42}$ Ministry of Education and Culture, "Data Referensi Kementerian Pendidikan Dan Kebudayaan" (Jakarta: MOEC, 2020), https://referensi.data.kemdikbud.go.id/index21.php?kode=0766.

${ }^{43}$ Asfi Manzilati, "Metodologi Penelitian Kualitatif: Paradigma, Metode, Dan Aplikasi” (Malang: Universitas Brawijaya Press, 2017), https://books.google.co.id/books?hl=en\&lr=\&id=7FlVDwAAQBAJ\&oi=fnd\&pg=PR5\&dq=subyek+dan +obyek+penelitian\&ots=Y57y9h_rf_\&sig=DIZKusqDHiczY9UXiM2idssh6nI\&redir_esc=y\#v=onepage $\& \mathrm{q}=$ subyek dan obyek penelitian $\& \mathrm{f}=$ false.

${ }^{44}$ Muh. Fitrah \& Luthfiyah, "Metodologi Penelitian: Penelitian Kualitatif, Tindakan Kelas \& Studi Kasus” (Sukabumi: Jejak, 2018). 
through the concluding steps, is done by reviewing the review of all field notes, reflecting on what has been interpreted to be developed becomes conclusions. ${ }^{45}$

\section{RESULT AND DISCUSSION}

Internalization of humanist values for young children facing COVID-19 pandemic in the city of Padangsidimpuan carried out varied. Internalization varies according to the mother's knowledge and experience as a guardian, guide and caregiver, and educator of children. ${ }^{46}$ The mother carried out internalization as the first God transmitter educator. Mothers who are closest to early childhood. Mothers who best understand the condition of children. Children are the desire and pride of every parent. Children can be a solace, a complement to the household's joy, the successor of the struggle, investment, teachers, partners, and even protective parents, especially when parents are elderly. ${ }^{47}$

Mothers, of course, always crave and hope that their children will be able to make them happy, becoming a heart conditioner and solace. Many mothers carrying out routine tasks in the family carrying out activities at home is always responsible for holding the mandate. Every training at home (work from home) recommends restoring the mother's role as a wise educator, a caring protector, patient caregivers, patient caregivers, loving relatives, polite sponsors, and have dedication. The mother's role as an educator at home is a mandate holder as the government itself gives full responsibility for education. ${ }^{48}$

Things that must be done by mothers in internalizing the values of humanism for early childhood in the face of the COVID-19 pandemic by:

1. Provide a clear and accurate understanding of information about the Covid 19 pandemic knowledge through social media and printed explanations. Strengthening the internalization of the value of gratitude (gratitude).

\footnotetext{
${ }^{45}$ Nursyaidah, "Metodologi Penelitian Disertai Dengan Contoh Penerapannya Dalam Penelitian," 2018.

46 Mrs. N, "Interview with employee of The Office of The National Program for Community Development of Padangsidimpuan City" (Southeast Padangsidimpuan, 2020).

47 Asfiati, "The Use of Application Neuroscience in Facing the Industrial Revolution 4.0 the Principals of Senior High School Over the Branch of the Education Department The Use of Application Neuroscience in Facing the Industrial Revolution 4 . 0 the Principals Of," Journal of Physics 1387, no. 1 (2019): 1-6, https://doi.org/10.1088/1742-6596/1387/1/012112.

48 Suyadi and Sutrisno, "A Genealogycal Study of Islamic Education Science at the Faculty of Ilmu Tarbiyah Dan Keguruan UIN Sunan Kalijaga,” Al-Jami'ah 56, no. 1 (2018): h.3, https://doi.org/10.14421/ajis.2018.561.29-58.
} 
2. Mother told about the steps taken to follow government policies through public health.

3. Mother invites the children to study together and enter values about how important it is to work together.

4. Mother provides education and lessons about science, health, leadership technology, and shows self-identity.

This finding is supported by the results of an online questionnaire distributed to 60 respondents: The distribution of the questionnaire showed that of 60 respondents whose mothers had early childhood 0-8 years internalized various humanist values, as follows:

Mothers as parents internalize humanist values and try to give attention and support, to encourage children. Calm can minimize psychological stress. Abdullah mentioned that "psychological pressure is assumed to create social injustice, discrimination." In order to avoid psychological stress, maximum attention, advice and attention to the child is given first as a conditioning of the heart. Psychological tranquility affects early childhood attitudes with the hope of not experiencing interference.

The survey results found that mothers are also more easily anxious in dealing with a pandemic 19 before work from home (WFH). It was found that $84 \%$ of mothers were worried in dealing with covid pandemic 19 while at home. $16 \%$ of mothers could control themselves in coping with covid pandemic 19. This statement was supported by interviews with several respondents, stating that: COVID-19 pandemic is both frightening and worrying. ${ }^{49}$ Then with work from home (WFH), mothers are increasingly confined and anxious, and worried. ${ }^{50}$ Repetitive and monotonous home activities cause concerns. ${ }^{51}$ Mothers must be multi-talented mothers as teachers, mothers as caregivers, mothers as entertainers of children and families. ${ }^{52}$ Many things are done to overcome the mother's anxiety by familiarizing the family atmosphere through humanist values. The mother internalizes the humanist value into the mother herself then is transmitted to the child. The survey results found that mothers are also more

\footnotetext{
${ }^{49}$ Mrs. D, "Interview with the housewife" (Padangsidimpuan Batunadua, 2020).

${ }^{50}$ Mrs. M, "Interview with housewife" (North Padangsidimpuan, 2020).

${ }^{51}$ Mrs. P, "Interview with housewives" (North Padangsidimpuan, 2020).

52 Mrs. Ma, "Interview with Elementary School Teachers" (Padangsidimpuan Hutaimbaru, 2020)
} 
easily anxious in dealing with a pandemic before work from home (WFH). It was found that $84 \%$ of mothers were worried in dealing with covid pandemic while at home.

Sixteen percent of mothers could control themselves in dealing with covid pandemic 19. This statement was supported by interviews with several respondents, stating that: COVID-19 pandemic is both frightening and worrying. Then with work from home (WFH), mothers are increasingly confined and anxious, and worried. Repetitive and monotonous home activities cause concerns. Mothers are required to be multi-talented. Mothers as teachers, mothers as caregivers, mothers as entertainers of children and families. The mother internalizes the humanist value into the mother herself then is transmitted to the child. ${ }^{53}$ Humanist values about patience, self-integrity, self-control, self-instruction, self-introduction. ${ }^{54} \mathrm{I}$ hope to minimize anxiety by internalizing humanist values to early childhood through mothers who have also been imprinted on attitudes and attitudes with humanist values that are patient, heartconditioned, steadfast, grateful, and beneficial.

COVID-19, showing $80 \%$ of children have a high curiosity. There is no curiosity $3.3 \%$ and $11.7 \%$, just the possibility of curiosity about the pandemic COVID-19. The high level of curiosity of early childhood about the COVID-19 pandemic follows the nature and character of children aged 0-8 years. The character stages in children take place systematically and continuously. The child's curiosity is the individual figure of the child himself. ${ }^{55}$

Children's high curiosity to know the COVID-19 pandemic information becomes an easy step for mothers to internalize humanist values to early childhood in various ways. Based on an online survey results, it was found that $83.3 \%$ of mothers shared it with stories, $11.7 \%$ with other means, and $5 \%$ through anecdotes and history. Internalize stories about good stories of Prophets and Apostles. ${ }^{56}$ Covid pandemic information 19 through stories about educational figures and local cultural figures was delivered by the mother. ${ }^{57}$ Thus the child is increasingly able to understand and accept the co-pandemic condition 19. Understanding something that is worrying and can be controlled makes

\footnotetext{
53 Mrs. F, "Interview with IAIN Padangsidimpuan lecturer" (South Padangsidimpuan, 2020).

${ }^{54}$ Asfiati, "Internalisasi Pendekatan Humanis Dalam Kurikulum Tersembunyi."

55 Amrullah, "Pembentukan Karakter Jujur Dan Sabar Anak Usia Dini Persfektif Al Qur'an,” ElMoona, Jurnal Ilmu Pendidikan Islam 2, no. 1 (2020): h.78.

${ }^{56}$ Mrs. A, "Interview with IAIN Padangsidimpuan lecturer" (Southeast Padangsidimpuan, 2020).

${ }^{57}$ Mrs. RA, "Interview with MAN 2 Padangsidimpuan teacher" (North Padangsidimpuan, 2020).
} 
the child able to be pro-social when viewed from the child's activities, social relationships, and environmental functions. ${ }^{58}$

The mother is ready to become a children's learning guide. The survey shows that $72.9 \%$ of mothers become children's learning guides during work from home (WFH). At the time, the mother became a child learning guide. At the same time, the mother internalized human values to face the pandemic COVID-19. She shared the role with other family members by $21.2 \%$. Mothers who are not supervising children's learning are $5.9 \%$.

Raziq Ramadhan said: During school hours, mothers always reminded them to go to school, and the children did their daily activities. Mother told me to wake up at dawn, pray, get ready to go to school, even at home. School uniforms remain worn until after school hours. Mother advised that discipline, resilience, persevering, be yourself. Mother always said that being a schoolchild, always obedient to parents, respect the teacher, note to the creator. The teacher is the mother. Always happy. Thankful for the pandemic COVID-19. Thank God you can gather at home and manage yourself to become independent. ${ }^{59}$

The survey findings and interview results make each child, through internalization of human values, more mature and self-reliant. Researches produce research that is always grateful for mental health, physical health, social relations, grit, the ability to survive in difficult situations to rise again and be robust to the spiritual. ${ }^{60}$

Humanist values by building the ability to rise again so that children face copandemic 19 as a lesson in life. Humanist values produce children capable of running schools at home and please parents, brothers, and sisters in the family environment. Thankful there are mothers, fathers, brothers, and sisters who are always there in life in the family.

Humanist internalization for young children faces co-pandemic 19 by conveying positive things. As the axis of education in the family environment, the mother provides

58 Revina Rizqiyani and Adisti Asmodilasti, "Perilaku Prososial Anak Taman Kanak-Kanak Dilihat Dari Pendidik Anak Usia Dini," AWLADY : Jurnal Pendidikan Anak 6, no. 1 (March 30, 2020): 110-23, https://doi.org/10.24235/awlady.v6i1.4189. 2020

${ }^{59} \mathrm{Mr}$. RR, "Interview with 8-year-olds in grade 2 elementary school"(North Padangsidimpuan,

${ }^{60}$ Nina Mariana, Abdul Azis, and Iwan Setiawan, "Pengembangan Kecerdasan Spiritual Anak Usia Dini Melalui Homeschooling," Tarbiyat Al-Aulad: Jurnal Pendidikan Islam Anak Usia Dini 4, no. 1 (March 4, 2020), https://riset-iaid.net/index.php/TA/article/view/416. 
information about the pandemic COVID-19 accurately, clearly, and updated. The survey results prove $77.9 \%$ submitted complete and accurate information. Not submitted complete $7 \%$ and only information that is likely to be correct $15,1 \%$. Mother provides information from recognized social media, such as television, and avoids news and information that is not a hoax.

The information conveyed by the mother about the COVID-19 pandemic affects the child. The survey results prove $86.5 \%$ affect, have no effect on $4.2 \%$, and may have an impact and may have no effect on $9.3 \%$. This finding is essential for the mother to pay attention to when internalizing humanist values. Pandemic 19 must be given clearly and accurately. In order not to cause anxiety for children. Q.S Al Baqoroh 155 states that: "And honestly we will provide you trials, with a bit of fear, hunger, lack of wealth, soul and fruit. And give good news to those who are patient ".

Covid pandemic 19, better known as a disease caused by a new coronavirus that has not been known to humans before. ${ }^{61}$ The stress of receiving covid information. As the respondents' answers in Padangsidimpuan that $69.8 \%$ of stressed children received information from mothers about the pandemic COVID-19. No stress 14\%. $16.3 \%$ more may cause stress.

The survey results explained that all mothers provided information about the government's appeal about co-opt 19 19\%. Data from the spiritual aspect is also given where the mother increasingly invites children to get closer to the creator of the virus, God. And when the call to prayer was echoed by the mother internalizing the power of God. It was found that every region in Padangsidimpuan 100\% still echoed the call to worship in the mosques during the Fardhu prayer. The study results found that: giving children humanist values when caring for, guiding children by providing spiritual Ilahiah by inviting children to instill religious, reading al-Qur'an requesting prayer in the congregation to study Islamic leaders capable of giving birth to children who have gratitude and benefit class. ${ }^{62}$ You can do this through the spiritual interpretation of God.

${ }^{61}$ Shihab Quraish, Corona Ujian Tuhan Sikap Muslim Menghadapinya (Jakarta: Lentera Hati, 2020).

62 Salafuddin Salafuddin et al., "Pola Asuh Orang Tua Dalam Penguatan Pendidikan Karakter Anak (Studi Kasus Pada Anak TKW Di SDN Pidodo Kecamatan Karangtengah)," JPAI: Jurnal Perempuan Dan Anak Indonesia 2, no. 1 (March 1, 2020): 18-30, https://doi.org/10.35801/jpai.2.1.2020.28276. 


\section{CONCLUSION}

The COVID-19 pandemic teaches individuals to socialize themselves from subjectivity to objectivity. To encourage and minimize anxiety and anxiety in the face of the co-pandemic 19, it is important to internalize humanist values for early childhood. According to the National Association for the Education of Young Children (NAEYC), PAUD is an association of child educators based in America, where 08 years of age have physical, cognitive, socio-emotional, creativity, language, and communication patterns. development.

Early childhood development needs to be directed, addressed, and given full attention. Habitual behavior can be done by positive thinking. Positive thinking for yourself and others. Studying together at home is part of and incorporates values about how important it is to work together. The position of the mother as an educator results in a more perfect education. Mother and child become a team for successful teaching. The value of egalitarianism in education in the family is internalized so that children and mothers understand the importance of needing each other.

\section{REFERENCES}

Abdullah, Muhammad Luthfi. "Religious Cultural-Based Educational Model Through Mentoring to Form Islamic Humanistic Values." Istawa: Jurnal Pendidikan Islam (IJPI) 5, no. 1 (2020): 1-18. https://doi.org/10.24269/ijpi.v5i1.2234.

Al-Hazmi, Ali. "Challenges Presented by MERS Coronavirus, and SARS Coronavirus to Global Health." Saudi Journal of Biological Sciences, 2016. https://doi.org/10.1016/j.sjbs.2016.02.019.

Amrullah. "Pembentukan Karakter Jujur Dan Sabar Anak Usia Dini Persfektif Al Qur'an.” El-Moona, Jurnal Ilmu Pendidikan Islam 2, no. 1 (2020): h.78.

Anjelina, Lidia, Dey Putri, Elindra Yetti, and Sofia Hartati. "Pengaruh Keterlibatan Orangtua Dan Regulasi Diri Terhadap Perilaku Bullying Anak Usia Dini." Jurnal Obsesi: Jurnal Pendidikan Anak Usia Dini 4, no. 1 (2020): 715-32. https://doi.org/10.31004/obsesi.v4i2.438.

Asfi Manzilati. "Metodologi Penelitian Kualitatif: Paradigma, Metode, Dan Aplikasi." Malang: Universitas Brawijaya 2017. https://books.google.co.id/books?hl=en\&lr=\&id=7FlVDwAAQBAJ\&oi=fnd\&pg= PR5\&dq=subyek+dan+obyek+penelitian\&ots=Y57y9h_rf_\&sig=DIZKusqDHiczY 9UXiM2idssh6nI\&redir_esc=y\#v=onepage\&q=subyek dan obyek penelitian\& $\mathrm{f}=$ false.

Asfiati. "Internalisasi Pendekatan Humanis Dalam Kurikulum Tersembunyi." Darul Ilmi 07, no. $01 \quad$ (2019): $45-59 . \quad$ http://jurnal.iainpadangsidimpuan.ac.id/index.php/DI/article/view/1804/1563. 
Pendekatan Humanis Dalam Pengembangan Kurikulum. Bandung: Perdana Publishing, 2016.

"The Use of Application Neuroscience in Facing the Industrial Revolution 4 . 0 the Principals of Senior High School Over the Branch of the Education Department The Use of Application Neuroscience in Facing the Industrial Revolution 4 . 0 the Principals Of." Journal of Physics 1387, no. 1 (2019): 1-6. https://doi.org/10.1088/1742-6596/1387/1/012112.

Azis, Abdul. "Pendidikan Islam Humanis Dan Inklusif." Al-MUNZIR 9, no. 1 (March 24, 2020): 1-12. https://doi.org/10.31332/am.v9i1.773.

Beck, Matthias, and Damian Tobin. "The 2019/2020 Novel Coronavirus Outbreak: An International Health Management Perspective." The Open Public Health Journal 13, no. 1 (2020): 52-54. https://doi.org/10.2174/1874944502013010052.

Badri, Khairul Nizam bin Zainal, and Hari Khrisnan Andi. "Kepentingan Pendidikan Humanistik Dalam Pengembangan Psikologi." Dinamika Jurnal Ilmiah Pendidikan Dasar 12, no. 1 (April 5, 2020): 33-43. https://doi.org/10.30595/dinamika.v12i1.5902.

Buana, Dana Riksa. "Analisis Perilaku Masyarakat Indonesia Dalam Menghadapi Pandemi Virus Corona (COVID-19) Dan Kiat Menjaga Kesejahteraan Jiwa." SALAM: Jurnal Sosial Dan Budaya Syar-I 7, no. 3 (2020): h. 218. https://doi.org/10.15408/sjsbs.v7i3.15082.

Crollios, Georgios. Paulo Preire and The Curriculum. New York: Roudledge, 2016. https://books.google.co.id/books?id=SRbvCgAAQBAJ\&pg=PT176\&dq=Paulo+Fr eire,+2002:+195\&hl=id\&sa=X\&ved=0ahUKEwijr6XH_p3pAhWLaCsKHcl_CM wQ6wEILTAA\#v=onepage \&q=Paulo Freire\%2C 2002\%3A 195\&f=false.

Eti Nurhayati. "Memahami Tumbuh Kembang Anak Usia Dini:Perspektif Psikologi Perkembangan." Awlady: Jurnal Pendidikan Anak, 1, no. 2 (2015): 1-14.

Fermadi, Bayu. "Humanisme Sebagai Dasar Pembentukan Etika Religius; Dalam Perspektif Ibnu Athā'Illah Al-Sakandarī." Jurnal Islam Nusantara 2, no. 1 (2018): 72. https://doi.org/10.33852/jurnalin.v2i1.71.

Gates, Bill. "Responding to COVID-19 - A Once-in-a-Century Pandemic?" The New England Journal of Medicine, 2020. https://doi.org/10.1056/NEJMp2003762.

Gustina, Fatma. "Perkembangan Kognitif Anak Usia 4-5 Tahun Di TK Islam.” Jurnal Pendidikan Anak Awlady 6, no. 1 (2020). https://www.syekhnurjati.ac.id/jurnal/index.php/awlady/article/view/5592/2913.

Ibda, Hamidullah. "Kontekstualisasi Humanisme Religius Perspektif Mohammed Arkoun." At-Tajdidi-Jurnal Ilmu Tarbiyah 9, no. 1 (2020): 17-48. http://ejournal.stitmuhpacitan.ac.id/index.php/tajdid/article/view/159/78.

Indonesia, Presiden Republik. Undang-Undang Republik Indonesia Nomor 20 Tahun 2003 Tentang Sistem Pendidikan Nasional. Sekretaris Negara Republik Indonesia. Vol. 19. Jakarta, 2003. https://kelembagaan.ristekdikti.go.id/wpcontent/uploads/2016/08/UU_no_20_th_2003.pdf.

Kemendikbud. "Data Referensi Kementerian Pendidikan Dan Kebudayaan." Padangsidimpuan: Kemendikbud, 2020. 
https://referensi.data.kemdikbud.go.id/index21.php?kode=0766.

Khaeriyah, Ery. "Membangun Kesadaran Moral Melalui Pendidikan Anak Usia Dini." Jurnal Pendidikan Anak Awlady 1, no. 2 (2015): 1-14.

Kumar, Dharmendra. "Coronavirus: A Review of COVID-19." Eurasian Journal of Medicine and Oncology, 2020. https://doi.org/10.14744/ejmo.2020.51418.

Lin, Qianying, Shi Zhao, Daozhou Gao, Yijun Lou, Shu Yang, Salihu S. Musa, Maggie H. Wang, et al. "A Conceptual Model for the Coronavirus Disease 2019 (COVID19) Outbreak in Wuhan, China with Individual Reaction and Governmental Action." International Journal of Infectious Diseases, 2020. https://doi.org/10.1016/j.ijid.2020.02.058.

Liu, Ying, Albert A. Gayle, Annelies Wilder-Smith, and Joacim Rocklöv. "The Reproductive Number of COVID-19 Is Higher Compared to SARS Coronavirus." Journal of Travel Medicine 27, no. 2 (2020): 1-4. https://doi.org/10.1093/jtm/taaa021.

Luthfiyah, Muh. Fitrah \&. "Metodologi Penelitian: Penelitian Kualitatif, Tindakan Kelas \& Studi Kasus." Sukabumi: Jejak, 2018.

Madjid, Mohammad, Payam Safavi-Naeini, Scott D. Solomon, and Orly Vardeny. "Potential Effects of Coronaviruses on the Cardiovascular System: A Review." JAMA Cardiology, 2020. https://doi.org/10.1001/jamacardio.2020.1286.

Mariana, Nina, Abdul Azis, and Iwan Setiawan. "Pengembangan Kecerdasan Spiritual Anak Usia Dini Melalui Homeschooling." Tarbiyat Al-Aulad: Jurnal Pendidikan Islam Anak Usia Dini 4, no. 1 (March 4, 2020). https://risetiaid.net/index.php/TA/article/view/416.

Maulana, Ihsan, and Nurhamidah Nasution. "Pengenalan Konsep Perkalian Menggunakan Media Rak Telur Rainbow Pada Anak Usia Dini Abstrak." Jurnal Obsesi: Jurnal Pendidikan Anak Usia Dini 4, no. 2 (2020): 512-19. https://doi.org/10.31004/obsesi.v4i2.370.

Mehta, Puja, Daniel F. McAuley, Michael Brown, Emilie Sanchez, Rachel S. Tattersall, and Jessica J. Manson. "COVID-19: Consider Cytokine Storm Syndromes and Immunosuppression." The Lancet 395, no. 10229 (2020): 1033-34. https://doi.org/10.1016/S0140-6736(20)30628-0.

Nugroho, Puspo. "Internalisasi Nilai-Nilai Karakter Dan Kepribadian Mahasiswa Pendidikan Agama Islam Melalui Pendekatan Humanis-Religius." Edukasia: Jurnal Penelitian Pendidikan Islam 12, no. 2 (2017): 355. https://doi.org/10.21043/edukasia.v12i2.2491.

Nursyaidah. "Metodologi Penelitian Disertai Dengan Contoh Penerapannya Dalam Penelitian," 2018.

Pfefferbaum, Betty, and Carol S. North. "Mental Health and the COVID-19 Pandemic." New England Journal of Medicine, 2020. https://doi.org/10.1056/nejmp2008017.

Purnama, Sigit, and Laily Hidayati. "Pengasuhan Anak Usia Dini Dalam Hikayat Indraputra." Jurnal Obsesi: Jurnal Pendidikan Anak Usia Dini 4, no. 2 (2020): 520-42. https://doi.org/10.31004/obsesi.v4i2.391.

Rizqiyani, Revina, and Adisti Asmodilasti. "Perilaku Prososial Anak Taman Kanak- 
Kanak Dilihat Dari Pendidik Anak Usia Dini." AWLADY : Jurnal Pendidikan Anak 6, no. 1 (March 30, 2020): 110-23. https://doi.org/10.24235/awlady.v6i1.4189.

Salafuddin, Salafuddin, Santosa Santosa, Slamet Utomo, and Sri Utaminingsih. "Pola Asuh Orang Tua Dalam Penguatan Pendidikan Karakter Anak (Studi Kasus Pada Anak TKW Di SDN Pidodo Kecamatan Karangtengah)." JPAI: Jurnal Perempuan Dan Anak Indonesia 2, no. 1 (March 1, 2020): 18-30. https://doi.org/10.35801/jpai.2.1.2020.28276.

Sastradiharja, Edy Junaedi, Farizal Ms, and Al Firdaus. "Kecerdasan Interpersonal Humanistik Dalam Perspektif Al-Qur'an." Andragogi: Jurnal Pendidikan Islam dan Manajemen Pendidikan Islam 2, no. 1 (March 25, 2020): 1-17. https://doi.org/10.36671/andragogi.v2i1.80.

Saurabh Mitra, and Jayati Chatterjee Mitra. "A Focus on Coronavirus (COVID-19)." International Journal of Research in Pharmaceutical Sciences 11, no. SPL1 (2020): 23-30. https://doi.org/10.26452/ijrps.v11ispl1.2009.

Shihab Quraish. Corona Ujian Tuhan Sikap Muslim Menghadapinya. Jakarta: Lentera Hati, 2020.

Steven J. Taylor, ,Robert Bogdan .Marjorie DeVaultIntroduction to Qualitative Research Methods: A Guidebook and Resource. 4th ed. Canada: Jhon Wiley \& Sons Incs Hoboken,New Jersey, 2016. https://books.google.co.id/books? id=jauBCgAAQBAJ\&printsec=frontcover\&dq=i nauthor:\%22Marjorie+DeVault\%22\&hl=id\&sa=X\&ved=0ahUKEwirj5bkpvpAhUL4XMBHf3CDCUQ6AEIKDAA\#v=onepage \&q\&f=false.

Sumantri, Budi Agus. "Teori Belajar Humanistik Dan Implikasinya Terhadap Pembelajaran Pendidikan Agama Islam." Foundatia Jurnal Pendidikan Dasar 3, no. 2 (2019): 1-18. https://doi.org/https://doi.org/10.36088/fondatia.v3i2.216.

Suyadi, and Sutrisno. "A Genealogycal Study of Islamic Education Science at the Faculty of Ilmu Tarbiyah Dan Keguruan UIN Sunan Kalijaga.” Al-Jami'ah 56, no. 1 (2018): h.3. https://doi.org/10.14421/ajis.2018.561.29-58.

Udin, Tamsik. "Mengenali Anak Usia Dini Melalui Pertumbuhan Perkembangan Dan Karakteristiknya." AWLADY : Jurnal Pendidikan Anak 1, no. 2 (August 31, 2015). https://doi.org/10.24235/awlady.v1i2.744.

UNICEF. "Dampak Pandemic Coronavirus 2019-2020 Bagi Pendidikan." Cambridge International Examinations, 2020. ttps://translate.google.com/translate?u=https://en.wikipedia.org/wiki/Impact_of_th e_2019\%25E2\%2580\%259320_coronavirus_pandemic_on_education\&hl=id\&sl=e $\mathrm{n} \& \mathrm{tl}=\mathrm{id} \& \mathrm{client}=\mathrm{srp}$.

WHO. "\#Covid19 Coronavirus Disease 2019: Situational Report 72." DroneEmprit 2019, no. April (2020): 1-19. https://pers.droneemprit.id/covid19/.

"Novel Coronavirus-China". WHO. Retrieved April 9 2020." World Health Organization, 2020. https://www.who.int/indonesia/news/novel-coronavirus.

. "Statement on the Second Meeting of the International Health Regulations (2005) Emergency Committee Regarding the Outbreak of Novel Coronavirus (2019-NCoV) January 302020 Statement Geneva, Switzerland." World Health Organization, 2020. https://www.who.int/news-room/detail/30-01-2020-statement- 
on-the-second-meeting-of-the-international-health-regulations-(2005)-emergencycommittee-regarding-the-outbreak-of-novel-coronavirus-(2019-ncov).

Widiyati, Setiani, Anita Chandra, and Purwadi Purwadi. "Analisis Kecemasan Anak Tk Di Awal Masuk Sekolah Dalam Interaksi Didalam Kelas Di Kecamatan Pedurungan Kota Semarang." Yaa Bunayya : Jurnal Pendidikan Anak Usia Dini 3, no. 2 (December 27, 2019): 91-96. https://doi.org/10.24853/yby.3.2.91-96.

Yani, Ahmad, Ery Khaeriyah, and Maulidya Ulfah. "Implementasi Islamic Parenting Dalam Membentuk Karakter Anak Usia Dini Di RA At-Taqwa Kota Cirebon." Jurnal Pendidikan Anak Awlady 3, no. 1 (2017): h.153-174. www.syekhnurjati.ac.id/jurnal/index.php/awlady.

Yunika, Nurheliza, and Ria Novianti. "Hubungan Konsep Diri Dengan Perilaku Moral Anak Usia Dini." Aulad: Journal on Early Childhood 2, no. 3 (2019): 73-80. https://doi.org/10.31004/aulad.v2i3.36.

\section{Interview}

Mrs. A., "Interview with MAN 2 Padangsidimpuan teachers." North Padangsidimpuan, 2020.

Mrs. A. "Interview with IAIN Padangsidimpuan lecturers." Southeast Padangsidimpuan, 2020.

Mrs. A. "Interview with Raudhatul Athfal teacher." Southeast Padangsidimpuan, 2020.

Mrs. D. "Interview with housewives." Padangsidimpuan Batunadua, 2020.

Mrs. F. "Interview with IAIN Padangsidimpuan lecturer." South Padangsidimpuan, 2020.

Mrs. M. "Interview with housewives." North Padangsidimpuan, 2020.

Mrs. Ma. "Interview with elementary school teacher." Padangsidimpuan Hutaimbaru, 2020

Mrs. N. "Interview with employee of The Office of The National Program for Community Development of Padangsidimpuan City." Southeast Padangsidimpuan, 2020.

Mrs. P. "Interview with housewives." North Padangsidimpuan, 2020.

Mrs. R, R. "Interview with children aged 8 years of grade 2 elementary school level." North Padangsidimpuan, 2020.

\section{Observation}

Observation. "The city of Padangsidimpuan is in an atmosphere of the COVID-19 pandemic." Padangsidimpuan City, 2020.

- "The condition of housewives conveying information on the COVID-19 pandemic in the City of Padangsidimpuan." Padangsidimpuan, 2020.

-. "The condition of the people of Padangsidimpuan City in 6 districts and cities, namely in the North Padangsidimpuan District, South Padangsidimpuan, Southeast Padangsidimpuan, Padangsidimpuan Batunadua, Padangsidimpuan Hutaimbaru, Padangsidimpuan Angkola." Padangsidimpuan, 2020.

- "The delivery of teacher information about home study did not have an accurate basis."

Padangsidimpuan,

2020. 